\title{
BMJ Global Health Queen bee in a beehive: WHO as meta- governor in global health governance
}

\author{
Sara Van Belle, ${ }^{1}$ Remco van de Pas, ${ }^{1,2}$ Bruno Marchal ${ }^{3}$
}

To cite: Van Belle S, van de Pas R, Marchal B. Queen bee in a beehive: WHO as meta-governor in global health governance. BMJ Glob Health 2017;3:e000448. doi:10.1136/ bmjgh-2017-000448

Handling editor Seye Abimbola

Received 23 June 2017 Revised 24 January 2018 Accepted 25 January 2018

Check for updates

${ }^{1}$ Department of Public Health, Health Policy Unit, Institute of Tropical Medicine, Antwerp, Belgium

${ }^{2}$ Maastricht Centre for Global Health, Maastricht University, Maastricht, The Netherlands ${ }^{3}$ Department of Public Health, Health Systems Unit, Institute of Tropical Medicine, Antwerp, Belgium

Correspondence to

Dr. Sara Van Belle;

svanbelle@itg.be
In this journal, Lee and Smith lament the lack of institutional innovation in the WHO, arguably the crux of global health governance $(\mathrm{GHG}){ }^{1}$ They contend that WHO can only regain its leadership role if it focuses on 'enabling consensus in a nimble and timely manner' and foremost, if it supports 'mechanisms to facilitate the formation of networks, sharing of resources, generation of ideas and enabling of decision-making across constituencies that are not confined to states alone'. Like Mackey, ${ }^{2}$ they argue for a radical, innovative shift in GHG as complex global health challenges can no longer be borne by WHO alone. Lee and Smith rightly consider network governance as the leading institutional design to guide 21st century GHG.

In the light of events related to WHO's reform of the past year, we would like to focus on what this networked model-WHO looks like and specifically of how WHO could play the meta-governor role. Democratic networked or interactive governance has been advanced as the 'best fit model' for both national governments and the international order to face current complex realities. ${ }^{3}$ A recent addition to network governance as a model for global health governance is Anne-Marie Slaughter's work, which urges us to move from the 19th century 'chessboard game' thinking to the 'web'.

Margetts $e t a \tilde{l}$ describe our age as one of 'chaotic pluralism', an era where a hodgepodge of different forms of more or less durable organisations, of tight or loosely coupled networks, webs and individuals, of half-truths and the negation of the value of expertise, ${ }^{6}$ all vie for our attention. Social media mushroomed to the extent that it is now affecting social change ${ }^{7}$ and indeed altering global collective action. To assert its leadership, WHO must transform into a queen bee reigning over a beehive of chaotic pluralism.

What does 'chaotic pluralism' mean for WHO reform? We argue that in this densely networked global health world, WHO needs first to keep at its role of enabling consensus
Summary box

A number of authors advocate for a radical, innovative shift in global health governance, as complex global health challenges cannot be longer be borne by WHO alone.

- Network governance emerged as a leading institutional design to guide 21st century global health governance.

- We argue WHO needs to take up the role of meta-governor, for which it should ensure five key functions: consensus building among different sets of actors and networks, steering, ensuring policy coherence, facilitating knowledge innovation through exchange and learning and finally, ensuring democratic accountability.

- WHO may need to reconsider its divisionalised bureaucratic structure and move towards a 'beehive' configuration. In order to be better deal with the complexities of global health, it should become a learning organisation with relational capabilities and a matrix structure, which is loosely coupled to key issues, networks and actors.

among actors and issuing evidence-based guidelines. It should thus renew its claim to authority and legitimacy in global health governance, reclaiming guidance in global health learning and expertise.

In an inherently unstable multipolar world, there is some merit in continued collaboration and sharing responsibilities on guaranteeing global public goods such as on global health, climate change mitigation and the Sustainable Development Agenda. WHO remains, unless its member states and key funders decide otherwise, a main diplomatic platform to guide the global health agenda.

Meaningful (re-)connecting to a broad range of actors would allow the organisation to respond to the increasing complexity of the global demos. Intergovernmental membership organisations such as WHO should open up to innovative ways of decision-making and institutional engagement with a wide array of actors, with transparent rules for their representation in an accountable manner. ${ }^{8}$ This requires a major overhaul 
of WHO, whereby both the trap of an overenthusiastic embrace of Slaughter's 'network mindset" and, on the other hand, the pitfall of excessive new formalism needs to be avoided. ${ }^{9}$ Furthermore, we agree with McCoy and Garrett that WHO needs to reach out to disenfranchised groups, establishing a connection with local critical collective action and local agents of change. ${ }^{10}{ }^{11}$ It needs to contribute to building a global civic culture-although without co-opting it. ${ }^{12}$ One of the primary functions of WHO should be to ensure inclusiveness and democratic accountability of the processes for which it is responsible.

Regarding the global health 'meta-governor' function, WHO should ensure five key functions: consensus building among different sets of actors and networks, steering, ensuring policy coherence, facilitating knowledge innovation through exchange and learning and finally, ensuring democratic accountability. ${ }^{13}$ Accountability is what sets meta-governance apart from mere network coordination or consensus building. It draws the attention to public accountability, on which its claim to global health leadership ultimately rests. Contrary to popular imagination, networks are not inherently 'good' nor are international non-governmental organisations (NGOs) always representative of the powerless in global policy deliberations. ${ }^{14}$ Holding such networks accountable to the public is a key function a meta-governor should ensure. ${ }^{15}$ In essence, the five key 'governance' functions should be operationalised along the four essential functions of the Global Health System: production of Global Public Goods, management of externalities across countries, mobilisation of global solidarity and stewardship. ${ }^{16}$

Complex health issues, such as Ebola epidemics and antimicrobial resistance, are the true test beds for WHO's meta-governance role. Meta-governance would include the strategic use of networks to collect data and to coordinate the emergency response. The use of such 'action networks' ${ }^{4}$ in times of crisis, however, relies on a long-term investment in a much wider array of different types of actors: intergovernment and non-governmental networks, epistemic (knowledge) and policy communities and in the as of yet untapped potential of regional organisations. Civic capital and citizen demand will have to be nurtured.

WHO has tried to take up the 'meta-governor' function over the years, for instance, by more firmly engaging with non-governmental actors. In the early 2000s, WHO Director General Brundtland established the Civil Society Initiative, a renewed policy for more effective collaboration, information exchange and dialogue with Civil Society Organisations. ${ }^{17}$ However, the World Health Assembly (WHA) did not formalise this initiative, due to opposition from a group of member states. Later, Kickbush and colleagues proposed for the WHA to become a 'superstructural node' in polilateral health diplomacy (involving structural relationships with non-state entities), suggesting an additional 'committee $\mathrm{C}$ ' to the WHA that would deal with coherence, partnership and coordination and where member states could engage with other global health actors. ${ }^{18}$ This model was also resisted by member states. Finally, as part of the recent WHO reform in 2016, the WHA adopted a Framework of Engagement with Non-State Actors (FENSA) after 5 years of difficult negotiations. This framework is considered a step forward in democratising the policy debate, but there are concerns that FENSA is an insufficient response to the part the private sector plays in determining global health action and population-level health outcomes. ${ }^{19}$ For instance, emergency response and preparedness requires WHO to fully exercise its power given through the International Health Regulations (IHR) to act swiftly in crises and enforce compliance from state actors.

What does the meta-governor role entail in terms of organisational structure, processes, funding and legitimacy? First, WHO itself may need to reconsider its divisionalised bureaucratic structure and move towards a 'beehive' configuration. It should become a learning organisation with relational capabilities and a matrix structure, which is loosely coupled to key issues, networks and actors. Crucial in such structural change is the capacity of monitoring, learning, generating and managing knowledge in a systematic manner. Such a move has some precedents. It was already noted in early 2000 that the IHR function should move to a networked governance mode, by including non-state actors in the process of global infectious disease surveillance. ${ }^{20}$ One could argue that today's Global Outbreak and Alert Response Network is another expression of this move towards networked governance.

It is also essential to understand the political economy of chaotic pluralism in GHG. Sridhar and Woods note that the funding of several global health initiatives can be considered under the light of 'Trojan multilateralism, creating the illusion of multilateral intent, whereas it is covertly introducing bilateral goals and interests into multilateral institutions. ${ }^{21}$ We acknowledge the need to advance institutional innovation and networked governance as suggested in the examples by Lee and Smith. However, each of the proposals for institutional change requires a careful assessment and public dialogue on the interests, legitimacy and underlying values being advanced. ${ }^{22}$ At this moment, many global health actors are still too far removed from this dialogue on reform and mechanisms to enhance the voice from marginalised groups are underused.

Any change in institutional redesign of WHO without greater financial autonomy is likely to fall flat. Dr Tedros Adhanom takes the reins of an organisation that is very sensitive to political pressure from its members. Although WHO's mandate is collectively set by its Member States, the organisation can only do what it is actually funded for, which depends on the interests of a handful of major donors. For instance, countries consistently rank addressing non-communicable diseases as their primary health concern, but this is one of the programmatic areas in which $\mathrm{WHO}$ has the most difficulty securing donor funding. Unfortunately, post-Ebola reforms have so far 
not triggered much needed innovative financial investments in the organisation. ${ }^{23}$ Only $20 \%$ of the organisation's overall budget is guaranteed by the member states. The rest remains voluntary, tied programme funding. Despite the pressure for WHO to take a leadership role in future global health crises, its member States have only agreed on a mere $3 \%$ increase in assessed contributions (core budget) during the 2017 World Health Assembly.

We now turn to a function, which we feel was not sufficiently given attention in Lee and Smith's call for innovation in GHG. The major challenge in adapting the WHO to an age of chaotic pluralism is the function of ensuring democratic legitimacy. The WHO reform of the last years focused on ensuring that the organisation becomes more effective, transparent and accountable. A remaining major challenge is enhancing the deliberation with and representation of relevant actors in global health policymaking, while at the same time preventing potential conflicts of interests harming the global public good function of WHO. Such conflicts of interest are far from being virtual. The horizontal policymaking processes and the networks and partnerships in global health governance have been dominated by a global elite that is well represented in epistemic communities and issue networks. Their discussions seem, at times, far removed from everyday citizen's needs and problems. Such disconnect may contribute to the current representation crisis, which is feeding into the cynicism of the ordinary citizen regarding politics in general. WHO can only regain its leadership role when it can formulate an answer to this lack of representation. ${ }^{24}$

Complementary to the above, WHO is part of the United Nations family and the broader global governance architecture. There is much debate on how to move beyond the current institutional gridlock and shift towards a more open collaborative, 'adaptive' governance. ${ }^{12}$ The world has shifted to a 'multiorder' system in which international cooperation takes place (or fails to do so) in totally different ways in separate areas. There have been several innovative proposals to locate WHO closer to key UN governance mechanisms. Ottersen and colleagues have argued for a UN multistakeholder platform on global governance for health, supplemented by an independent scientific monitoring panel responsible for health equity impact assessments. ${ }^{25}$ Reflecting on Global Health Security needs, Mackey has summarised proposals on a UN high-level panel on Global Health, with potentially close connections to the UN Economic and Social Council and/orthe UN Security Council. ${ }^{2}$ The Rethinking the Global Health Architecture project came up with a range of reform proposals, including a proposition to create a 'UN-HEALTH'. ${ }^{26}$

To a certain extent, this 'shift' to move global health higher up the international political agenda has already taken place. For a decade now, the United Nations General Assembly has included a Foreign Policy and Global Health Initiative, preparing yearly resolutions and ensuring that crucial issues, such as health security
(Ebola), communicable diseases such as malaria, and health system issues such as maternal health and universal health coverage receive high-level attention. ${ }^{27}$

Outside the UN, global health has emerged on the global political agenda, for instance, of the G8/G20, the World Trade Organisation, the United Nations Framework Convention on Climate Change and the World Social and Global Security Forums. It also has become of higher importance to regional organisations such as the African Union, the European Union and the Association of Southeast Nations. The WHO's change in leadership might enhance its political savviness and diplomatic capacity to be involved in these arenas. ${ }^{28}$

In conclusion, in times of multiorder and chaotic pluralism in global health, we should allow for political imagination and conceptualise alternative views of organising global health, including a way of viewing a global health citizenry. ${ }^{12}$ At the same time, urgent global health challenges require leadership and a legitimate institution, a 'meta-governor', to be in charge. WHO is undergoing a period of creative instability. Dr Tedros is torn between two contradictory positions. WHO's Member States want more operationalisation and impact, but this should not damage WHO's already overstretched human and financial resources to work on its normative purpose (organisational mission). ${ }^{28}$ Tedros has to effectively tackle this balancing act for WHO to engage in collective priority setting. With so many vultures preying on the death of multilateralism, this complex task of deliberative priority setting has to be fully acknowledged by the global health community and fully supported.

Acknowledgements We thank our colleague Kristof Decoster (Institute of Tropical Medicine, Antwerp) for providing comments on draft versions of the article.

Contributors SVB and BM drafted the initial manuscript. RvdP contributed to the final manuscript and the revision. All authors have seen the manuscript and agree with authorship.

Competing interests None declared.

Provenance and peer review Not commissioned; externally peer reviewed.

Open Access This is an Open Access article distributed in accordance with the Creative Commons Attribution Non Commercial (CC BY-NC 4.0) license, which permits others to distribute, remix, adapt, build upon this work non-commercially, and license their derivative works on different terms, provided the original work is properly cited and the use is non-commercial. See: http://creativecommons.org/ licenses/by-nc/4.0/

(C) Article author(s) (or their employer(s) unless otherwise stated in the text of the article) 2017. All rights reserved. No commercial use is permitted unless otherwise expressly granted.

\section{REFERENCES}

1. Smith R, Lee K. Global health governance: we need innovation not renovation. BMJ Glob Health 2017;2:e000275.

2. Mackey TK. The Ebola outbreak: catalyzing a "Shift" in Global Health Governance? BMC Infect Dis 2016;16:699.

3. Torfing J, Peters BG, Pierre J, et al. Advancing the paradigm. Oxford University Press: Oxford, 2012.

4. Slaughter AM. The chessboard and the web. Strategies of connection in a networked world. New Haven: Yale University Press, 2017.

5. Margetts H, John P, Hale S, et al. How social media shape collective action. Princeton University Press: Princeton, 2016. 
6. Nichols T. The death of expertise. The campaign against established knowledge and why It matters. Oxford University Press: Oxford, 2017.

7. Kavada A. Social movements and political agency in the digital age. Media and Communication 2015:4.

8. Hale T, Held F, Young K. Gridlock: why global cooperation is failing when we need it the most. London: Polity Press, 2013.

9. Torfing J, Peters BG, Pierre J, et al. Interactive governance. Oxford: Oxford University Press, 2012.

10. Garrett L. Global health in a populist and nationalist age. J Int Aff 2017.

11. McCoy D. Critical global health: responding to poverty, inequality and climate change comment on "politics, power, poverty and global health: systems and frames". Int J Health Policy Manag 2017;6:539-41.

12. Van Belle S, Contractor SRethinking health governance. Towards an inclusive and political health citizenship Institute of Tropical Medicine Antwerp (accessed 22 Dec 2017). http://www.internationalhealthp olicies.org

13. Bell S, Hindmoor A, Governance R. The centrality of the state in modern society. Cambridge: Cambridge University Press, 2009.

14. Scholte AJ, Democracy BG. Civil society and accountable global governance. Cambridge: Cambridge University Press, 2011.

15. Van Belle S. Accountability in sexual and reproductive health How relations between INGOs and state actors shape public accountability. A study of two local health systems in Ghana: University of London, 2014.

16. Frenk J, Moon S. Governance challenges in global health. $N$ Engl J Med 2013:368:936-42.

17. Lee K. Civil society organizations and the functions of global health governance: what role within intergovernmental organizations? Glob Health Gov 2010;3.
18. Kickbusch I, Hein W, Silberschmidt G. Addressing global health governance challenges through a new mechanism: the proposal for a Committee C of the World Health Assembly. J Law Med Ethics 2010;38:550-63.

19. Buse K, Hawkes S. Sitting on the FENSA: WHO engagement with industry. Lancet 2016;388:446-.

20. Fidler DP. SARS: political pathology of the first post-Westphalian pathogen. J Law Med Ethics 2003;31:485-505.

21. Sridhar D, Woods N. Trojan multilateralism: global cooperation in health. Glob Policy 2013;4:325-35.

22. McNeill D, Ottersen OP. Global governance for health: how to motivate political change? Public Health 2015;129:833-7.

23. Moon S, Leigh J, Woskie L, et al. Post-Ebola reforms: ample analysis, inadequate action. BMJ 2017;356:j280.

24. Papadopoulos Y. The Democratic Quality of Collaborative Governance. Levi-Faur D, ed. Oxford handbook of governance. Oxford: Oxford University Press, 2012:512-26.

25. Ottersen OP, Dasgupta J, Blouin C, et al. The political origins of health inequity: prospects for change. The Lancet 2014;383:630-67.

26. Schafferhof M, Suzuki E, Angelides P, et al. Rethinking the global health system. Chatham House Royal Institute of International affairs. $2015 \mathrm{https}: / / \mathrm{www}$.chathamhouse.org/sites/files/chath amhouse/field/field_document/20150923GlobalHealthArchite ctureSchaferhoffSuzukiAngelidesHoffman.pdf

27. United Nations General Assembly. Global health and foreign policy: addressing the health of the most vulnerable for an inclusive society. New York: United Nations, 2017.

28. Horton R. Offline: The tasks facing Dr Tedros. The Lancet 2017;390:2538. 